\title{
Impact of the CAP on Archaeological Heritage. Cause \& Remedy?
}

\author{
Karl Cordemans, Vlaamse Landmaatschappii, Belgium \\ Emmet Byrnes, Forest Service Inspectorate, Department of Agriculture, Food and the \\ Marine, Ireland \\ Cees van Rooijen, Rijksdienst voor het Cultureel Erfgoed, the Netherlands
}

\begin{abstract}
This paper seeks to summarise the origin and evolution of the Common Agricultural Policy (CAP) in terms of the impact its policies and measures have had - and continue to have - on archaeological features and sites situated on arable land. The effects have been very obvious in some cases, less visible in others, but invariably significant. At the same time, the European policy on agriculture and rural development, and the Treaty provisions for the CAP can also present solutions and mitigation measures for the problems. Some examples will be presented within this paper, along with a forecast for the next programming period (2021-2027).

The authors are members of the EAA and EAC working group on Farming, Forestry and Rural Land Management. One of the aims of this working group is to improve the management of archaeological heritage in those areas.
\end{abstract}

Keywords: Policy, Common Agricultural Policy, Heritage Management, Stewardship

\section{Introduction}

The Burren Farming for Conservation Programme in County Clare, Ireland, nicely illustrates that modern agricultural practice with a view to making an economic return from any particular farm holding does not necessarily have to impact negatively on archaeological features and sites. The Burren Programme is a pioneering locally-led agri-environmental scheme which aims to conserve and support the heritage, environment, and communities of the Burren (Dunford 2016). It aims to ensure the sustainable agricultural management of High Nature Value farmland, contribute to the positive management of the Burren landscape and cultural heritage, and improve water quality and water use efficiency. Due to the variety of priority habitats it contains, including limestone pavement, orchid-rich grassland and turloughs, most of the Burren is also designated as part of the Natura 2000 Network under the EU Habitats Directive.

The Burren Programme has pioneered a novel 'hybrid' approach to farming and conservation which sees farmers paid for work undertaken and, most importantly, for the delivery of defined environmental 'products'. Its key principles focus on it being farmer-led, with minimal bureaucratic burdens, and results-based. Farmers are given the freedom to deliver the required outputs using their own skills, experiences, and resources that best fit their own 
farms and circumstances. Farmers have responded positively to their new role as 'leaders' in designing their farm plan; rather than telling them what to do they are asked what needs to be done. This has led to much better results. Last but not least, face-to-face advice and training are also a key part of the Burren Programme. Farm advisors undergo an intensive training course on farming for conservation and best management practices. A lot of effort is put into increasing the awareness and understanding among landowners of the archaeological monuments on their land.

The programme was funded through Life, EU's financial instrument supporting environmental, nature conservation and climate action projects, and the European Agricultural Fund for Rural Development (Pillar 1 of the CAP). The main problem with this approach has been that only land eligible for the Single Payments Scheme, according to the rules of the CAP, can receive payment under the Burren Programme. In practice that means about one-third of the Burren farmland cannot be funded due to the presence of rock outcrop and hazel scrub, as above certain narrow thresholds these features must be discounted from the area allowed to be claimed as Utilisable Agricultural Area (UAA). This has a perverse effect, giving farmers a strong incentive to reclaim/improve this ineligible ' 37 percent' to secure their entitlements, which leads to loss of landscape and natural heritage values in those relatively well-preserved areas.

In order to understand the working of the CAP and its impact on agriculture, a short history of the CAP is provided.

\section{The CAP}

CAP stands for the Common Agricultural Policy. The general objective of a common policy for agriculture was first established in 1957 when six countries (Germany, France, Italy, the Netherlands, Belgium, and Luxembourg) created the European Economic Community (EEC), the forerunner of the European Union (EU), and the Common Market with the signing of the Treaty of Rome (Teasdale \& Bainbridge 2012). Its context was the overarching political objective that the widespread hunger and starvation experienced in post-war Europe would never happen again, inter alia, by helping the severely-damaged agricultural sector to produce more food to aid self-sufficiency (in what was then a largely importdependant continent) and guarantee farmers an adequate standard of living. In order to disallow the normal competitive forces of the market, a key principle of the common policy for agriculture should be supported through a system of guaranteed minimum prices for particular products rather than direct aid for farmers' incomes.

In 1962, the CAP was formally launched. At that juncture, the EEC Member States were all strongly intervening in their agricultural sectors but these interventions posed an obstacle to the free trade in goods envisaged by the Treaty. To be able to maintain these strong State intervention policies, there was a need for them to be harmonised, and responsibility was transferred to the European Community level. Initially, the common policies were deemed to be working very well, with the EEC developing into a major producer and leading global exporter in dairy, meat and grain, as well as other products. However, by the 1970s and particularly in the 1980s, it became increasingly evident that overproduction was actually being encouraged and incentivised. Also, a transition towards more intensive and industrialised agriculture was induced. The results were large product surpluses known as butter mountains, milk, and wine lakes (Grant 1997), associated environmental problems, 
and criticism about the costs to community taxpayers (European Commission 2012).

In the following years, different measures were taken to stop the overproduction. Probably the best known of which are the 'set-aside' programmes and the 'production quota system'. This gradually reduced the huge product surpluses.

A first major change to the CAP came from the MacSharry Reform in 1992. Farmers no longer received support in relation to the products they produced, but relative to the area they farmed. It was only at this point in 1992 that making provisions for agri-environment schemes became compulsory for Member States, a first wary step in widening the scope of the CAP. However, participation remained voluntary for individual farmers. General provisions for afforestation and related forestry development schemes were also introduced (Batáry et al. 2015).

In 2000, the EU faced some major changes with preparations for the eastern enlargement of the Union. Plans for this expansion were set out in the Agenda 2000 action programme, which resulted in a new financial framework and new structural funds for the years 2000 to 2006. The Rural Development Programme became formalised as the so-called 'second pillar' to cope with important socio-economic and demographic changes affecting rural areas. It was agreed that greater emphasis should be given to environmental policy objectives and the multi-functional role of the European model of farming, again, a further widening of the CAP goals (Augère-Granier 2015).

With the mid-term review in 2003, direct payments were decoupled and cross-compliance was introduced. In order to be eligible for support, farmers were obliged to meet requirements regarding nature, water, and animal welfare.

In 2005, a new European agricultural fund was set up to finance the EU's rural development policy and national Rural Development Plan actions. In 2008, the so-called 'Health Check' of the CAP further boosted the decoupling in the direct payment system. This reform also increased the resources allocated to the second pillar, the pillar in which the 'wider' agricultural goals could be supported.

The current programming period, starting in 2014 and running until 2020, is characterised by the 'greening' of the CAP. Farmers now receive the green direct payment if they can show that they comply with three obligatory 'greening' practices which are good for the environment: crop diversification (planting a greater variety of crops to make soils and ecosystems more resilient), the dedication of $5 \%$ of arable land to areas beneficial for biodiversity, i.e. Ecological Focus Areas (EFA), and maintaining permanent grassland to support carbon sequestration and protect biodiversity. The agricultural fund for 2014 to 2020 is worth $€ 100$ billion, with a further $€ 61$ billion of public funding in the Member States themselves.

\section{Outlook for the next programming period 2021-2027}

On $1^{\text {st }}$ June 2018, the European Commission presented the latest legislative proposals for the CAP. It continues to support farmers and rural communities, leads the sustainable development of EU agriculture, and reflects the EU's ambition on environmental care and climate action. Member States are given greater flexibility and responsibility for choosing how and where to invest their CAP funding in order to meet goals set at the EU level. 
The new CAP will pursue the following specific objectives:

(a) Support viable farm income and resilience across the EU territory to enhance food security;

(b) Enhance market orientation and increase competitiveness including greater focus on research, technology and digitalisation ;

(c) Improve farmers' position in the value chain;

(d) Contribute to climate change mitigation and adaptation, as well as sustainable energy;

(e) Foster sustainable development and efficient management of natural resources such as water, soil and air;

(f) Contribute to the protection of biodiversity, enhance ecosystem services and preserve habitats and landscapes;

(g) Attract young farmers and facilitate business development in rural areas;

(h) Promote employment, growth, social inclusion and local development in rural areas, including bio-economy and sustainable forestry;

(i) Improve the response of EU agriculture to societal demands on food and health, including safe, nutritious and sustainable food, as well as animal welfare.

This might give the impression that landscape is not just present but prominent in the new Regulation. However, when looked at in detail (see Art. 43 of the Regulation proposal), there is no obligation to include specific actions regarding landscape. Member States are only offered the option to organise interventions regarding landscape, including historical features. As a consequence of this approach, when there are competing claims for measures and actions around climate change mitigation and adaptation and the environment and the sustainable management of natural resources, there will be even greater difficulty for heritage and archaeology managers to influence the development of the national Strategic Plans. Also lobbying by farmer representative bodies in support of certain actions or budgetary allocations over others will lead to an even smaller budget for landscape measures..

\section{Impact of the CAP on archaeology: cause}

Agriculture has an enormous impact on land use in Europe. About 11 million farms cultivate an average of $16 \mathrm{ha} /$ farm, resulting in 175 million ha or 40 percent of Europe. As a comparison, about 43 percent of Europe is forest land or 182 million ha (European Commission 2018). Since archaeological sites in towns and villages are in danger and often already damaged by continuous development and building phases, the majority of the bestpreserved sites are found precisely in these rural areas.

The Monuments at Risk Survey states that 10 percent of the archaeological sites in farmland in England is destroyed and 40 percent is damaged (Darvill \& Fulton 1998: 128-135). Other studies estimate that more than 30 percent has been lost through agriculture (O'Sullivan et al. 2001: 17). Pressures by agriculture and forestry are far greater than the pressures of development but are not subject to assessment and mitigation through the spatial planning system. 
Obvious and direct effects of the CAP are linked to the intensification and industrialisation of agriculture resulting from policy choices. Farms became bigger and more specialised. Fields became larger due to bigger and heavier machines, resulting in loss of boundaries and small landscape elements. Ploughing depth increased and the practice of sub-soiling became more widespread to mitigate soil compaction caused by heavy machinery (Fig. 1). When financial support was linked to the amount of area cultivated, the more marginal fields were drained, planed, ploughed, and fertilised. As a result, the overall erosion increased (Fig. 2) and hitherto relatively undisturbed soils were damaged. Around 13 percent of arable land in the EU is estimated to suffer from moderate to high erosion. This equates to an area of 140 $373 \mathrm{~km}^{2}$. Mean rates of soil erosion by water in the EU amounted to 2.5 tonnes per hectare per year (Panagos et al. 2015).

There are also less obvious, indirect effects of policy choices being made. Some of them are historic, but even at present and for the future it is important to consider the type of choices being made. In the recent past, one important factor to consider was the eligibility of crop type for income support. Depending on this, farmers chose their cultivation plan. Considering the increased erosion of crops such as potatoes, carrots and beets, this had an impact on the preservation of archaeological sites (Ruysschaert et al. 2004: 469-475). On the other hand, by changing the criteria for support from crop type to area, farmers expanded their holding area and started to put marginal fields to use too. Another example is the abolishment of the set-aside agreement, which was often applied to archaeological sites known as cropmark sites (subsurface archaeological sites only visible from the sky because of the different coloration of vegetation due to draught stress).

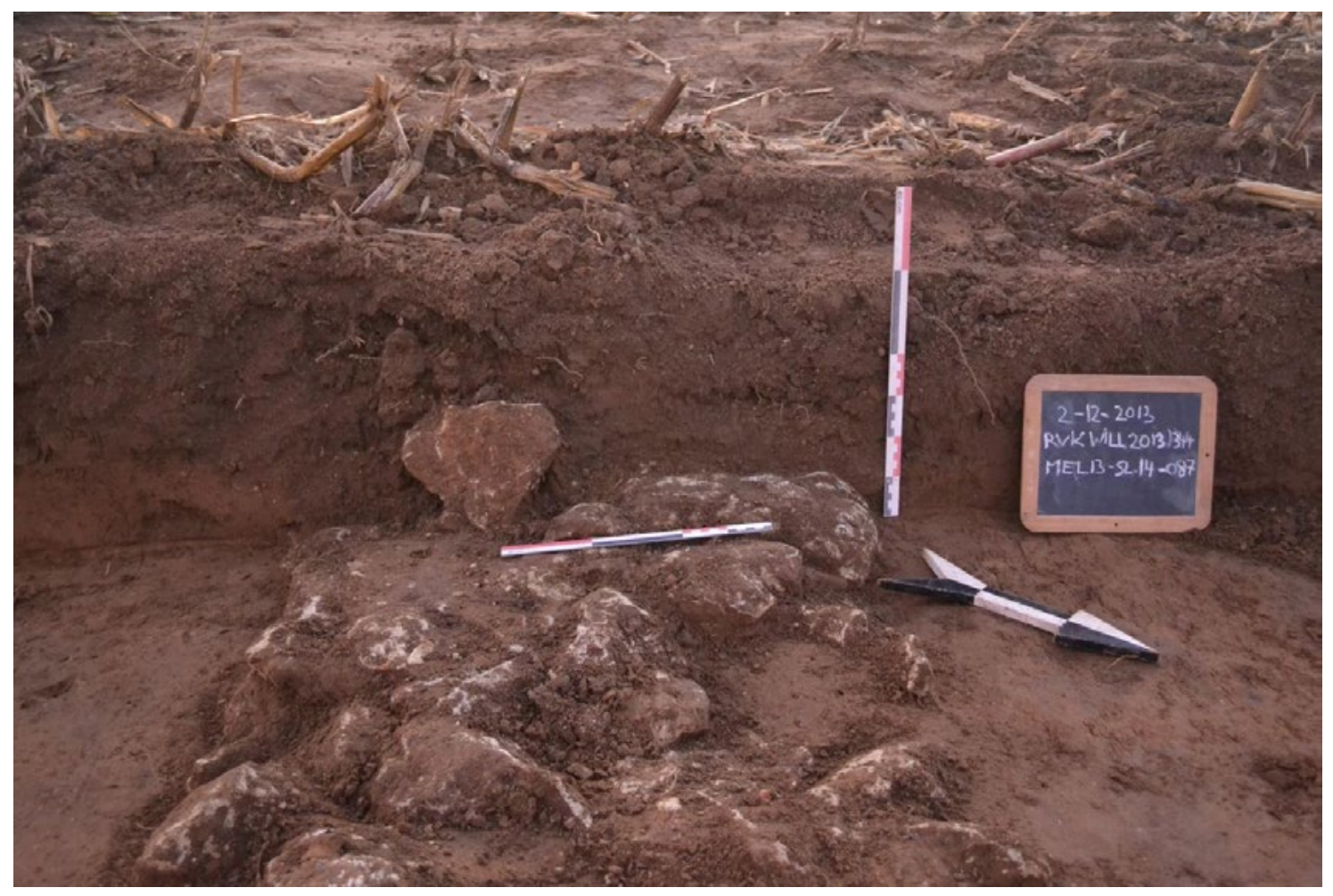

Figure 1. Archaeological remains of a Roman villa wall being ripped up by ploughing near Tienen, Belgium. Notice how close to the surface archaeological features are. (C VLM). 


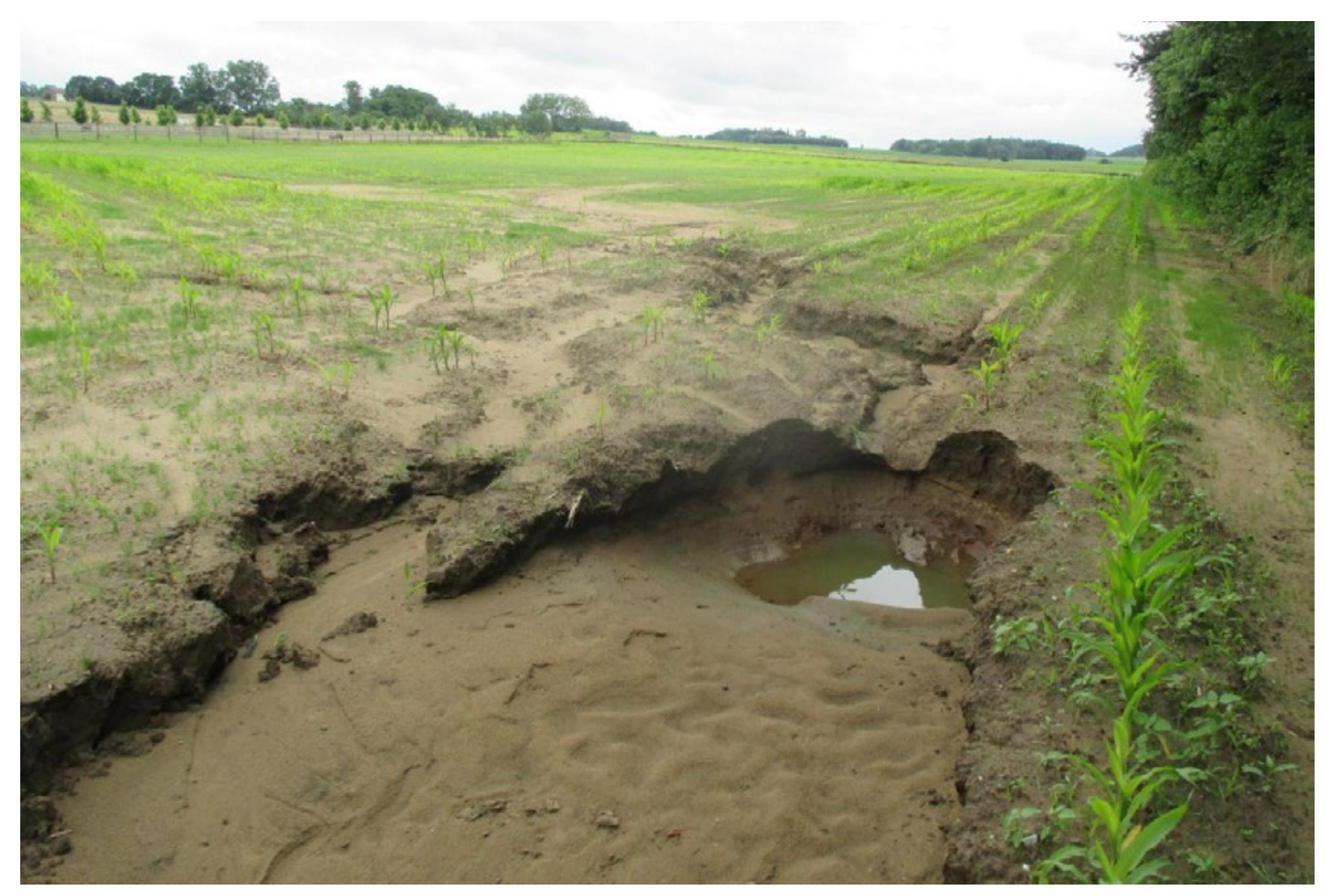

Figure 2. Illustration of erosion on the arable field due to heavy showers in spring (Tienen, Belgium) (C VLM).

When those fields were turned back into arable land, they were often ploughed deeper and resulted in further degradation of the archaeological features. Somewhat similar is the interpretation of 'permanent grassland' by each Member State. Of course, it makes a huge difference if the area of permanent grassland has to be maintained at field level, farm level or regional level. A final example is the definition of Ecological Focus Area, to which the Pillar 2 support is defined; when archaeological structures or ancient field boundaries are also taken into account, it can make a big difference for farmers to maintain these structures or to set them aside.

\section{Impact of the CAP on archaeology: remedy}

At the same time, the CAP makes it possible to mitigate some of the negative impacts. It can even provide a good framework for better protection and management of archaeological sites under arable land.

An 'obvious' example is cross compliance. In order to ensure that all agricultural land, especially land which is no longer used for production purposes, is maintained in Good Agricultural and Environmental Conditions (GAEC), Member States must define minimum requirements. These should be defined and take into account the specific characteristics of the areas concerned, including soil and climatic condition, existing farming systems, land use, crop rotation, farming practices, and farm structures. Depending on how the European Commission defines and formulates the standards, Member States will determine how the GAEC are interpreted and what farmers have to do to comply. The European Commission could, for instance, include the phrase "especially on known archaeological 
sites" in the standards for GAEC 5: Minimum land management reflecting site-specific conditions to limit erosion.

In the present CAP, all farmers with more than 15 ha of arable land are obliged to hold at least five percent of Ecological Focus Area (EFA), which means fallow land, field margins, buffer strips, hedges, and trees. If, for instance, the European Commission gives the implementation of EFA on known archaeological sites a higher weighting factor, this could help heritage managers in persuading farmers to take archaeological sites out of cultivation.

Member States are also obliged to set up a Farm Advisory System for helping farmers to better understand and meet the EU rules for the environment, public and animal health, animal welfare, and the GAEC. Member States can determine who gets access and what advice is provided. Why not choose a more holistic approach on farm holding level, taking agricultural, ecological and heritage-related aspects into account?

One of the most important instruments from the CAP Regulation is the agri-environment scheme, designed to encourage farmers to protect and enhance the environment on their farmland by paying them for the provision of environmental services. Farmers commit themselves to adopt environmentally-friendly farming techniques, for a minimum period of at least five years, that go beyond legal obligations. In return, farmers receive payments that provide compensation for additional costs and income foregone as a result of applying those environmentally-friendly farming practices in line with the stipulations of agri-environment contracts. Agri-environment measures may be designed at the national, regional, or local level so that they can be adapted to particular farming systems and specific environmental conditions. This makes agri-environment a targeted tool for achieving environmental goals. In the past programming periods, England and Ireland have had stewardship schemes that provided options for 'keeping the character of the countryside' and 'preserving features important to the history of the rural landscape encouraging educational access', which have been a huge support for the management of landscape and sites.

\section{Conclusion}

The CAP has (had) an enormous impact on the scale and intensity of agricultural practice and land management, and as such, mostly a negative impact on archaeological heritage. When looked at in detail, many positive examples can be found too, but these measures are often small-scale and depend on goodwill and private action. Most of the negative impact on archaeology is the result of political choices being made by Member States in which the archaeological heritage has not been taken into account. To change things for the better, the CAP should also be used as an important instrument. Raising awareness about the impact of the CAP on heritage - and how the CAP can be improved - is a starting point that could turn the tide. By making this shift, the CAP can become more sustainable and also compliant with wider environmental goals, including the preservation of archaeological heritage. 


\section{References}

Augère - Granier, M.L., 2015. EU rural development policy. European Parliamentary Research Service (EPRS), Members' Research Service EN PE 568.34. Accessed 4 July 2018.

http:/ / www.europarl.europa.eu/RegData/etudes / BRIE/2015/568340/EPRS_ BRI(2015)568340EN.pdf.

Batáry, P., Dicks, L.V., Kleijn, D. \& Sutherland, W.J., (eds), 2015. The role of agrienvironment schemes in conservation and environmental management. Conservation Biology 29, 1006-1016.

Darvill, T. \& Fulton, A., 1998. The Monuments at Risk Survey of England 1995. London:

School of Conservation Sciences, Bournemouth University, Bournemouth and English Heritage.

Dunford, B., 2016. The Burren Life Programme: An Overview. NESC Research Series Paper No. 9. Accessed 1 August 2018.

http://files.nesc.ie/nesc_research_series/Research_Series_Paper_9_BDunford_Burren.pdf. European Association of Archaeologists (EAA) 2019, EAA and EAC Working Group on farming, forestry and rural land management. Accessed November 2019. https:/ /www.e-a-a.org/ EAA/Communities/EAA_and_EAC_Working_Group_on_farming_forestry_and_rural_ land_management/EAA/Navigation_Communities/.

European Commission, 2012. The Common Agricultural Policy - A story to be continued. Accessed 10 July 2018. http:// ec.europa.eu/agriculture/50-years-of-cap/files/history/history_book_ lr_en.pdf.

European Commission, 2018. Environment. The results-based agri-environment schemes: Burren Farming for Conservation Programme (BFCP) - Ireland. Accessed 15 Oct 2018. http:/ / ec.europa. $\mathrm{eu} /$ environment/nature/rbaps/fiche/burren-farming-conservation-programme-bfcp_ en.htm.

Grant, W., 1997. Butter Mountains, Wine Lakes and Beef Wars: The Commodity Regimes, in: The Common Agricultural Policy. The European Union Series, 102-146.

O’ Sullivan, M., O’ Connor, D. \& Kennedy, L., 2001. Archaeological Features at Risk: A Survey Measuring Recent Destruction of Ireland's Archaeological Heritage. The Heritage Council of Ireland Series, 17.

https://www.heritagecouncil.ie/content/files/archaeological_features_at_risk_2001_4mb.pdf. Panagos, P., Borrellia, P., Poesen, J., Ballabio, C., Lugato, E., Meusburger, K., Montanarella, L. \& C. Alewell, 2015. The new assessment of soil loss by water erosion in Europe. Environmental Science \& Policy 54, 438-447.

Ruysschaert, G., Poesen, J., Verstraeten, G. \& Govers, G., 2004. Soil loss due to crop harvesting: significance and determining factors. Progress in Physical Geography 28, 467-501.

Teasdale A. \& T. Bainbridge, S.D., 2012. The Penguin Companion to European Union, additional website entry. Accessed 4 July 2018. https://penguincompaniontoeu.com/. 